\title{
IMMOVABLE PROPERTY TAX IN THE CZECH REPUBLIC AS AN INSTRUMENT OF FISCAL DECENTRALIZATION
}

\author{
Jana JANOUŠKOVÁ, Šárka SOBOTOVIČOVÁ \\ Department of Finance and Accounting, School of Business Administration in Karvina, Silesian \\ University in Opava, Univerzitní námèstí 1934/3, 733 40, Karviná, Czech Republic
}

Received 4 July 2016; accepted 11 September 2016

\begin{abstract}
The issue of fiscal decentralization is connected with efforts to build a space for own decision-making in municipalities when raising funds. In the framework of fiscal decentralization, municipalities in the Czech Republic have an opportunity to influence immovable property tax revenues. The aim of the research is to find out the municipalities' attitude towards the possibility of increasing immovable property tax revenues through a coefficient and how this option is used by municipalities. In the article, there is a description of the immovable property tax development in the Czech Republic on the basis of time series. The research relies on the evaluation of secondary statistical data and on the results of primary research focused on the application of the local coefficient. Municipalities have the option to edit tax components and the amount of tax reflects then the specificities and needs of the community. However, almost $92 \%$ of municipalities still postpone the introduction of a local coefficient. The motivation for the introduction of local coefficients was an increase in municipalities' revenues generally or the need to fund specific projects. On the other hand the empirical research showed that some form of compensation is introduced in $46 \%$ of the municipalities.
\end{abstract}

Keywords: compensation for tax, fiscal decentralization, immovable property tax, local coefficient, tax imposed, tax revenues.

JEL Classification: H70, H71.

\section{Introduction}

The issue of fiscal decentralization is connected with efforts to build a space for own decision-making in municipalities when raising funds. In the 90s, transitive economies faced the problem of autonomy renewal, delimitation of competencies in the selection of funding sources, or determination of their self-sufficiency in raising revenues. The immovable property tax is one of the stable incomes for municipalities which is assigned on them.

Corresponding author Šárka Sobotovičová

E-mail: sobotovicova@opf.slu.cz 
Although it is a marginal source of income, the government is forced to ponder about this source during unfavourable economic situation. Possible changes, leading to a boost in their revenues, are considered.

In particular, the issue of property valuation is addressed within the theoretical approaches and empirical studies, when their value represents the input for determination of the basis of the immovable property tax (Horne, Felsenstein 2010; Presbitero et al. 2014). The issue of an approach that should be adopted in the context of a potential increase in revenues for municipal budgets is also being solved (Coombs et al. 2012). There are also suggestions in the context of the ownership or tenancy relationship and especially which of them has a higher effect for increasing revenues from the immovable property tax (Brunner et al. 2015). Interesting effects can also be traced in the attitudes and relationships between fiscal federalism and a size of local governments (Liberati, Sacchi 2013).

The property tax revenues are not significant. According to Radvan (2007), they have been declining since the beginning of the 20th century in favour of more profitable indirect taxes and income ones. It is more than obvious that there are inconsistencies in the attitude to property taxes nowadays. One part of theoretical and practical levels favours an opinion that property taxes rather burden all taxation because of their insignificant contribution to public budgets. This argument is supported by the selection efficiency, when their yield is low due to other taxes, and injustice, when basically, it results in several taxation on the asset. However, political representation is reluctant to increase these taxes in the context of the potential amount of electoral votes (Bird 2011).

The opposite spectrum of opinions points out the positives of property taxes. They discuss a horizontal and vertical equity of the tax system and emphasize the stability of revenues (Bečica 2014; Birch, Sunderman 2013; Štreimikienè 2015). These taxes do not have a distorting effect on the job. They do not hold back economic activity to such an extent as income tax, which immediately reduce the revenue of work activities. These taxes should lead the owners of immovable to more rational and efficient control of the property (Slack 2011). The advantage of the immovable property tax is its characteristics, such as immobility of the real estate and good verifiability of its existence since it is a relatively stable part of the individual entities' assets. In the context of the Czech economy transformation in the 90s, the authors Smith, Bryson and Cornia (2011) scrutinize local perceptions of progress towards fiscal decentralization. The immovable property taxes may become an effective tool of fiscal decentralization (Haider-Markel 2014; Smiková, Sedmihradská 2011). Local governments use them to influence their own budgets in favour of improving the quality of life in the location of tax collection (Bird 2010; Marková 2007; Roubínek et al. 2015).

In the framework of fiscal decentralization, municipalities in the Czech Republic have an opportunity to influence immovable property tax revenues. The aim of the research is to find out the municipalities' attitude towards the possibility of increasing immovable property tax revenues through coefficients and how this option is used by municipalities. 


\section{Taxation of immovable property in the European Union}

The property taxes maintain a significant autonomy within the EU. Development of property taxation is moving in different directions and approaches are based mainly on national traditions (UN-HABITAT 2013). The number of property taxes and its amount differs most of all taxes in the EU Member States. But they have one thing in common. Their revenues flowing into government budgets are only a supplementary income. However, the fact that taxation of immovable property is introduced within the property tax is common for the EU States. And as it has been already mentioned, they are mostly a part of municipal budgets. Thus the principle of benefit is fulfilled (FAO Land Tenure Studies 2004; Mrkývka 2003).

The polarity of views on property taxes in the individual EU Member States gives rise to an interesting comparison and finding a base that would capture the strengths of different approaches to property taxes. The traditionalist United Kingdom is known for its conservative approach, respect the continuity of law and the tax laws; and even it reluctantly accedes to the stimuli from "outside" during creation of legislation.

In most European tax systems, the value of immovable property is used to determine the tax base (Blöchliger 2015; Hájek, Režný 2014). Revenues of such determined tax reflect inflation. Immovable property valuation for these purposes may not be in time accordance with economic development. Subsequently, insolvency of municipalities or tax hike may occur (Bird 2011). The tax base determined as follows faces problems in some countries. For example, Slovenia was considered to be a country with the latest databases of mass valuation of all immovable property functioning on the pricing models according to the type of immovable property (Žibik, Mitrović 2006). The law, which was updated on January 1, 2014, was already abolished in March 2014 by the Slovenian Constitutional Court.

Using of physical indicators (i.e. land area, built-up area, number of floors) is not preferred for taxation. It is only used in a small percentage of Member States, e.g. in the Czech Republic. Revenues of such calculated taxes are mostly low, and if these rates are not indexed for inflation, their share in the revenues of municipalities decreases significantly as well.

As it is clear from the following graph (Fig. 1), the largest share of property taxes and immovable property taxes in the total tax revenue can be seen in the United Kingdom. On the other hand, the lowest immovable property tax revenues are in Croatia and Luxembourg, and Malta does not levy the immovable property tax at all.

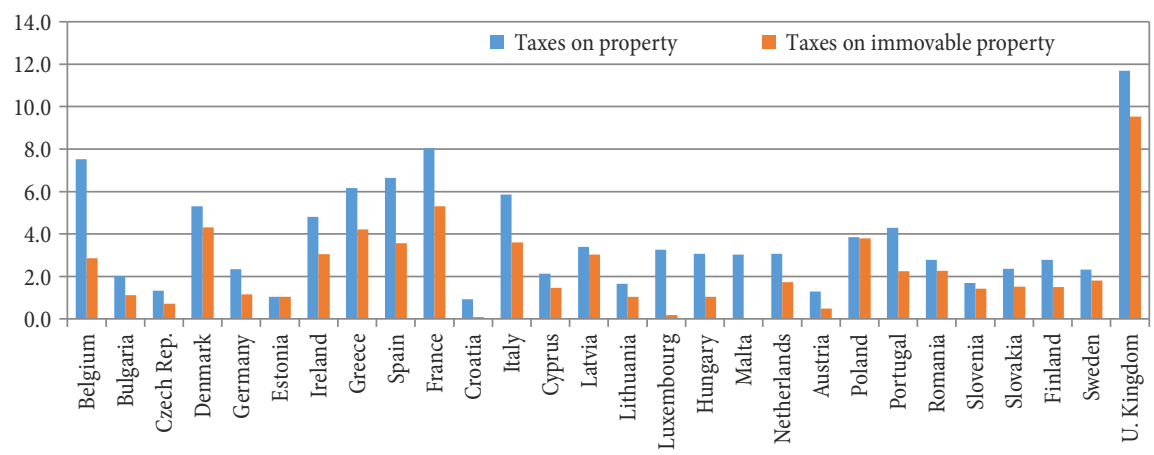

Fig. 1. Share of total property taxes and immovable property taxes in the EU States in 2012 in the total tax revenues (\%)

Source: The European Union (2014), own processing 


\section{Taxation of immovable property in the Czech Republic}

Property tax revenues in the Czech Republic belong to the lowest ones within the EU (the fourth lowest). Criticism of the low share of property taxes in the total tax revenue, particularly immovable property tax, is also expressed by the OECD (OECD 2010, 2011). The Czech Republic is recommended to use the market value of immovable property to determine the tax base. Similarly, the European Commission (European Commission 2015) assesses the revenues from immovable property tax to be very low, insufficiently linked to the fair value of immovable property and recommendations are aimed at strengthening these revenues (Zámečník et al. 2011).

In the Czech Republic, tax revenue from immovable property (until 2013 real estate) goes to the budget of the municipality in whose territory the immovable property is located (Sedmihradská 2013). The tax rates are set by law and the amount is the same for all municipalities. The municipality can affect the amount of revenues mainly through coefficients determined by generally binding ordinance. This is a corrective coefficient according to population, municipal and local coefficients.

The corrective coefficient is determined by law and depends on the number of inhabitants in the municipality. The municipality has the possibility to affect the amount of coefficient that for each area may be reduced by one to three categories or enhance one category. The coefficient is applied to residential buildings with other buildings appurtenances to them, units and construction sites.

The municipality may set a municipal coefficient at 1.5 and apply it to buildings used for family recreation, garages and buildings for business. The advantage of such coefficient is that it does not burden the objects for permanent housing, but a disadvantage is that the municipality cannot influence its amount.

In the context of strengthening fiscal decentralization, municipalities have had an extensive tool since 2009 which enables them to influence the amount of real estate tax revenues through a local coefficient of two, three, four and five. The whole calculated tax liability is multiplied by this coefficient, except for some land (arable land, hop gardens, vineyards, gardens, orchards and grassland). The coefficient applies to the municipality's territory and cannot be determined for a certain part of a locality only (Act No. 338/1992 Coll. 1992, on immovable property tax, as amended).

The local coefficient can be still considered the most effective tool by which the community as a beneficiary of the tax may significantly increase the yield of the immovable property tax on its territory. It can be used not only for long-term adjustment of tax revenues, but also temporarily for one or more taxable periods when disposable resources are needed to finance the necessary investment in the municipality. This, however, requires citizens' support, and this is probably the reason why a local coefficient is not used to a greater extent by communities.

In its introduction (i.e. 2009), 389 municipalities used the coefficient, which represents only $6.22 \%$ of the total number of municipalities in the Czech Republic. In 2010, the number of municipalities even declined to 283 municipalities. The cause of the coefficient cancellation for 189 municipalities was mainly a twofold increase in rates of built-up areas and 
yards, construction sites, other areas, and all types of buildings except for buildings used for business purposes. 83 municipalities newly introduced the coefficient. Only in 2012 the growth of 294 municipalities in the number of 416 (less than $7 \%$ of the total number of municipalities) was recorded. Although the number of municipalities with the applicable local coefficient increased to 519 in 2014, which is roughly one-third compared to 2009, it is still only about $8.3 \%$ of the total number of municipalities (Fig. 2).

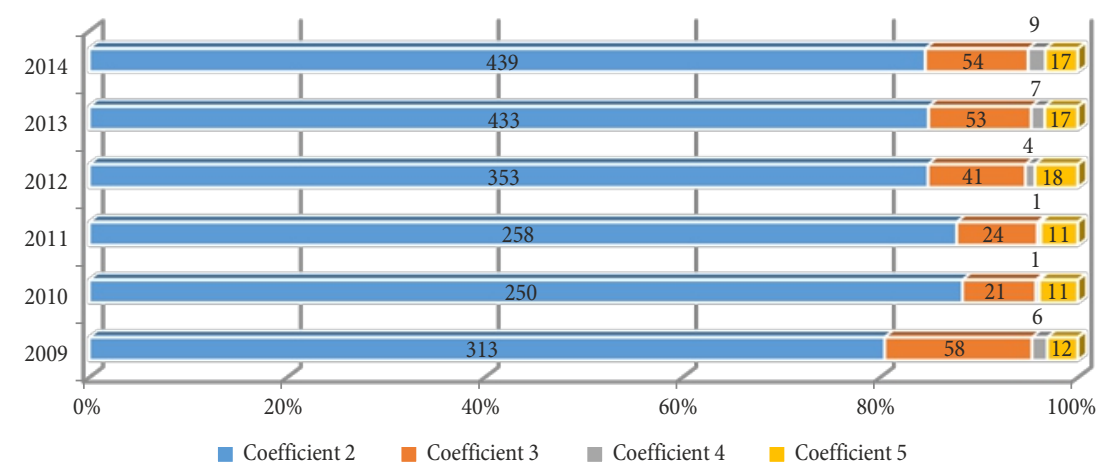

Fig. 2. Use of the local coefficient by municipalities between 2009 and 2014 Source: Tax administration 2015, own processing

The structure of municipal funds is diverse and consists of tax and non-tax incomes. Tax income is represented by taxes shared and assigned. Shared tax revenues are transferred on the basis of the law on the budgetary allocation of taxes and the municipality is unable to influence its amount. In contrast, the assigned taxes may respond to the actual costs in the municipality. Although the share of immovable property tax revenues on municipalities' income taxes was in average of 5.9\% in 2014 and a share of the total income of municipalities was only $3.6 \%$, they may influence the yields through coefficients (own calculation according MFCR 2014). Therefore, determination of the coefficients in each municipality becomes an important tool that should be used effectively on the basis of relevant analysis.

\section{Research objective and methods}

The primary objective of the research is to determine the attitude of municipalities to the possibility of an increase in immovable property tax revenues through coefficients. To achieve the stated objective, a questionnaire survey was used to determine:

- reasons leading municipalities to implement a local coefficient,

- whether the impact of the coefficient has been previously analysed,

- whether the increase in immovable property taxes is offset to citizens and how.

In the article, there is also a description of the immovable property tax development in the Czech Republic on the basis of time series tax revenues and tax imposed in response to legislative changes. The dynamics of the time series was investigated using basic features, namely absolute increase and growth rate. 
The absolute increase (first order differential) can be calculated according to formula

$$
\Delta y_{t}=y_{t}-y_{t-1}, t=2,3, \ldots, n,
$$

where $y_{t}$ - the value of the immovable property tax revenues (tax imposed) in the year $t$, $y_{t-1}$ - the value of the immovable property tax revenues (tax imposed) in the year $t-1$.

Growth rate in the year $t$ is calculated according to formula:

$$
k_{t}=\frac{y_{t}}{y_{t-1}}, t=2,3, \ldots, n
$$

where $y_{t}$ - the value of the immovable property tax revenues (tax imposed) in the year $t$, $y_{t-1}$ - the value of the immovable property tax revenues (tax imposed) in the year $t-1$.

Tax imposed represents the amount of tax as reported in tax returns and yield (Y) is calculated according to formula:

$$
Y=\frac{T R}{T I} \star 100
$$

where $T R$ - tax revenue, $T I$ - tax imposed.

To determine whether there is a significant difference in the approach to analysing and compensating tax increases depending on the size of the municipality, the chi-square test was used.

A contingency table was created, based on observed and expected frequencies which were calculated according to the following formula:

$$
E_{i j}=\frac{n_{i}}{n} \cdot \frac{n_{j}}{n} \cdot n=\frac{n_{i} n_{j}}{n},
$$

where $n_{i}$ - the sum of individual lines, $n_{j}$ - the sum of individual columns in the contingency table, $n$ - the sum of all observed frequencies.

The test criterion was calculated using the formula:

$$
T=\sum_{i=1}^{2} \sum_{j=1}^{s} \frac{\left(O_{i j}-E_{i j}\right)^{2}}{E_{i j}},
$$

where $s$ - the number of categories of a monitored variable.

Critical value $K=\chi_{\alpha}(s-1)$ of chi-squared distribution with a degree of freedom $\mathrm{df}=$ $s-1$ was calculated using Excel and the function CHIINV $(\alpha ; \mathrm{df})$ for the given level of significance $\alpha 0.05$ (Ramík, Perzina 2014).

To verify the accuracy, significance ( $p$-value) was calculated and was compared with the chosen significance level $(\alpha=0.05)$. The function CHIDIST (T; df) was used for the p-value calculation.

Methodically, the research relies on the evaluation of secondary statistical data of the Czech Statistical Office and the General Financial Directorate of the Czech Republic. The paper is also based on the results of primary research focused on the application of the local coefficient by municipalities, which was implemented in December 2014 with the help of a questionnaire survey through personal interviews, e-mails or phone. To make calculations, the data concerning the number and size of municipalities in the Czech Republic was used from the Czech Statistical Office. 


\section{Results and Discussion}

Development of regulations and immovable property tax collections in the Czech Republic from 1993 to 2014, including the absolute differences of the first order and growth factors, are listed in the following Table 1 . The tax revenue in each year is also listed.

Table 1. Development of regulations and immovable property tax collections in the Czech Republic from 1993 to 2014

\begin{tabular}{cccccccc}
\hline Year & $\begin{array}{c}\text { Tax } \\
\text { imposed }\end{array}$ & $\begin{array}{c}\text { Absolute } \\
\text { increase }\end{array}$ & $\begin{array}{c}\text { Growth } \\
\text { rate }\end{array}$ & $\begin{array}{c}\text { Tax } \\
\text { revenues }\end{array}$ & $\begin{array}{c}\text { Absolute } \\
\text { increase }\end{array}$ & $\begin{array}{c}\text { Growth } \\
\text { rate }\end{array}$ & Yields \\
\hline 1993 & 3600 & & & 3434 & & & 95.39 \\
\hline 1994 & 3783 & 183 & 1.05 & 3658 & 224 & 1.07 & 96.70 \\
\hline 1995 & 3769 & -14 & 1.00 & 3778 & 120 & 1.03 & 100.24 \\
\hline 1996 & 4100 & 331 & 1.09 & 3991 & 213 & 1.06 & 97.34 \\
\hline 1997 & 4098 & -2 & 1.00 & 3938 & -53 & 0.99 & 96.10 \\
\hline 1998 & 4336 & 238 & 1.06 & 4138 & 200 & 1.05 & 95.43 \\
\hline 1999 & 4477 & 141 & 1.03 & 4271 & 133 & 1.03 & 95.40 \\
\hline 2000 & 4475 & -2 & 1.00 & 4469 & 198 & 1.05 & 99.87 \\
\hline 2001 & 4604 & 129 & 1.03 & 4535 & 66 & 1.01 & 98.50 \\
\hline 2002 & 4640 & 36 & 1.01 & 4576 & 41 & 1.01 & 98.62 \\
\hline 2003 & 4841 & 201 & 1.04 & 4840 & 264 & 1.06 & 99.98 \\
\hline 2004 & 4864 & 23 & 1.00 & 4948 & 108 & 1.02 & 101.73 \\
\hline 2005 & 4917 & 53 & 1.01 & 4987 & 39 & 1.01 & 101.42 \\
\hline 2006 & 4978 & 61 & 1.01 & 5017 & 30 & 1.01 & 100.78 \\
\hline 2007 & 5023 & 45 & 1.01 & 5123 & 106 & 1.02 & 101.99 \\
\hline 2008 & 5104 & 81 & 1.02 & 5195 & 72 & 1.01 & 101.78 \\
\hline 2009 & 6318 & 1214 & 1.24 & 6361 & 1166 & 1.22 & 100.68 \\
\hline 2010 & 8671 & 2353 & 1.37 & 8747 & 2386 & 1.38 & 100.88 \\
\hline 2011 & 8676 & 5 & 1.00 & 8568 & -179 & 0.98 & 98.76 \\
\hline 2012 & 9576 & 900 & 1.10 & 9541 & 973 & 1.11 & 99.63 \\
\hline 2013 & 9855 & 279 & 1.03 & 9847 & 306 & 1.03 & 99.92 \\
\hline 2014 & 9828 & -27 & 1.00 & 9910 & 63 & 1.01 & 100.83 \\
\hline & & & & & & & \\
\hline
\end{tabular}

Immovable property tax revenues and tax imposed show a growing trend from 1993 to 2008. Since 2001, the trend of moderate growth has also had an impact on an improvement in the state register of real estate cadastre. Namely, it is transparency of the ownership in the renewal of cadastral documentation. The positive development of tax imposed and tax revenues also represent the result of an ongoing inspection and search operations of tax offices.

An increase in tax liability in 2009 was caused mainly by legislative changes. Particularly, it was the abolition of the exemption of newly completed construction of houses and buildings, where insulation had been carried out, and the introduction of the local coefficient by some municipalities. 
Immovable property tax revenues have increased significantly since 2010 mainly due to doubling the basic tax rate on all land, buildings and units (excluding parcels of agricultural land and buildings for other business activities). In 2011 there was a reduction in the tax revenues. It was partly caused by an increase in the volume of arrears, but primarily by additional reduction and a subsequent refund of tax for the previous tax year on the basis of certain court decisions concerning tax on buildings. Since 2012, there has been an increase in tax imposed and tax revenues as a result of the amendment, which seeks to tax paved areas of land used for business activities, and streamlining control and searching activity of tax administrators. Reorganization of tax administration and extensive checking of files relating to the immovable property taxes have had also a positive effect on tax revenues since 2013.

The Table 1 shows the yield of the immovable property tax is very good and it exceeds $100 \%$ in some years (due to the enforcement of arrears from previous years). The amount of uncollected taxes is primarily affected by the insolvency of large industrial enterprises and the lack of funding for operators of agricultural production. Even with a relatively small number of such entities and the amount of their tax liability, these factors also have a significant impact on the level of tax revenues.

The following graph (Fig. 3) indicates a similar trend in the rate of growth in both tax imposed and even tax revenues. A significantly higher coefficient for the two investigated variables is visible in the years 2009 and 2010 due to the possibility of establishing a local coefficient (since 2009) and a tax rates increase (since 2010). The yield coefficient is about 1, also in between 2009 and 2010, which was due to legislative changes related to immovable property tax imposed and tax revenues growth.

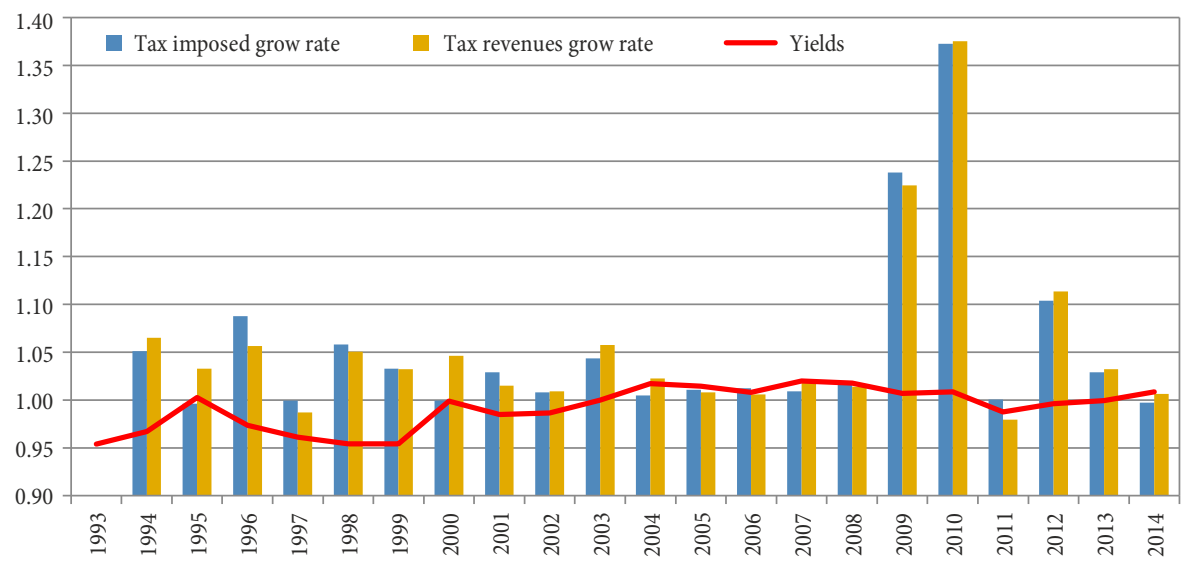

Fig. 3. Use of the local coefficient by municipalities between 2009 and 2014 Source: Tax administration 2015, own processing 


\section{Results of empirical research}

The research focused on exploring the use of immovable property tax coefficients by individual municipalities omit and was conducted by interviewing. The questionnaire represented a research instrument and questions, included in it, were both closed and open. Respondents were not submitted response options. The respondents answered using their words and responses were then grouped into semantic categories.

The application of a local coefficient in 2014 was a criterion for the selection of addressed municipalities. Out of the number 519 municipalities, 288 municipalities were addressed. 98 questionnaires were included into processing.

The structure of respondents (municipalities) by the amount of the local coefficients is displayed in Figure 4. The chart shows that among surveyed municipalities the coefficient 2 is used most frequently, which also corresponds to specifications in the national data in Figure 2.

Based on the legislative amendments, the municipalities have the possibility to establish the local coefficient effective since 2009. As it is evident from following Figure 5, the largest number of respondents has introduced the coefficient just this year.

Municipalities have the power to use the coefficient even for a limited period in the context of some investment. Most respondents (84) said they were applying the coefficient of the same amount; in 13 communities there was one change within the period of time; in one municipality there were two changes. The following year, four municipalities which introduced a local coefficient in 2009 cancelled it due to an increase in immovable property tax rates since 2010 .

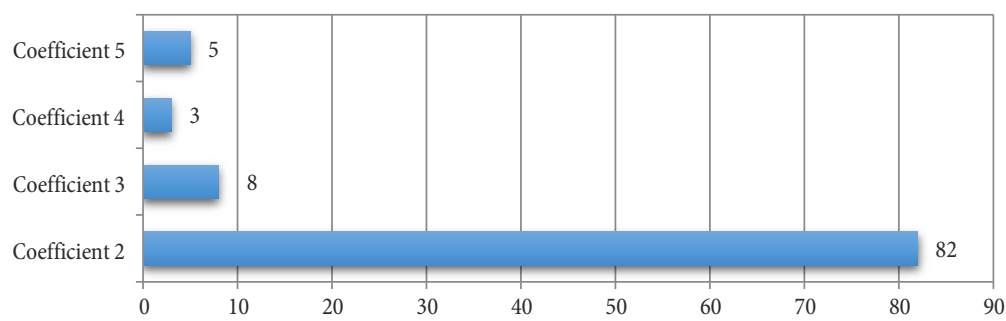

Fig. 4. Structure of respondents according to the amount of the local coefficient

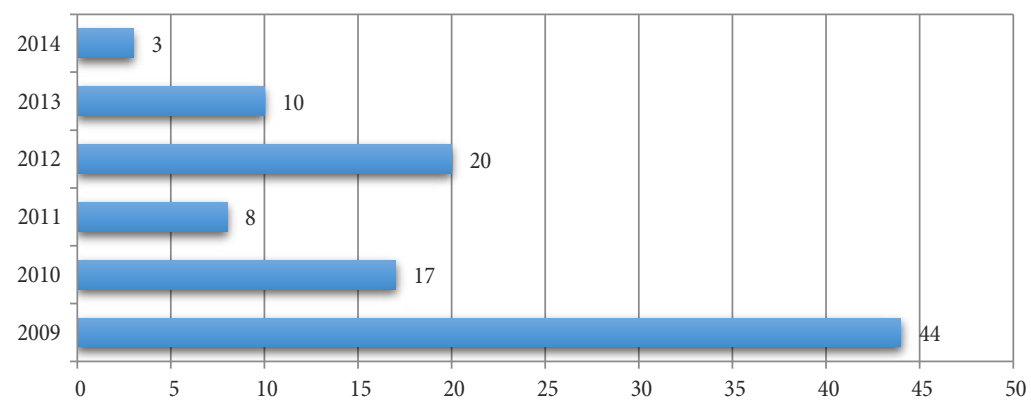

Fig. 5. Structure of respondents by the introduction of the local coefficient 
In addition to the local coefficient, the research concentrated on the fact how many municipalities have established a municipal coefficient. The use of the municipal coefficient is indicated in the following Table 2.

Table 2. Application of the municipal coefficient according to the municipality's size

\begin{tabular}{lcccccccc}
\hline $\begin{array}{l}\text { Number of } \\
\text { inhabitants }\end{array}$ & $200-499$ & $500-999$ & $1000-4999$ & $5000-19999$ & $20000-49999$ & $50000-99999$ & $100000+$ \\
\hline $\begin{array}{l}\text { Number of } \\
\text { cities }\end{array}$ & 2 & 8 & 21 & 12 & 7 & 2 & 1 \\
\hline
\end{tabular}

It was found that the municipal coefficient was only used by $54 \%$ of respondents. It was surprising because by means of this coefficient the immovable property tax can be increased without burdening constructions of permanent housing.

\subsection{Influence of the municipality's size on researched phenomena}

By using the chi-square test it was verified whether the size of the municipality influences its opinion in the analysis and compensation for the impact of local coefficient determination.

To determine the dependency analysis of the impact on the size of the municipality, null hypothesis $\mathrm{H1}_{0}$ was determined: Performing the analysis does not depend on the municipality's size.

Based on the results in the omit above Table 3 it can be concluded that the null hypothesis cannot be rejected. The fact whether the municipality carried out an analysis before introducing the local coefficient does not depend on its size. The costs incurred on the analysis mean a heavier financial burden for smaller municipalities. At the same time, the immovable property tax revenue represents a higher proportion of the total revenue for smaller municipalities (expressed as a percentage). Therefore, municipalities are more interested in the possibility of increasing revenues from this tax.

To determine the impact of compensation depending on the size of the municipality, null hypothesis $\mathrm{H}_{2}$ was determined: Compensation of citizens does not depend on the size of the municipality.

According to the values in the omit above Table 4 it is clear that we reject the null hypothesis. The fact whether the municipality compensates an increase in the immovable property tax depends on the size of the municipality. Based on empirical research it was found that the compensation is more than twice as frequent in municipalities with population up to 4.999 (56\%) than in larger municipalities (26\%).

Table 3.Verification of the hypothesis $\mathrm{H}_{0}$

\begin{tabular}{cc}
\hline CHI-SQUARE & 2.5412 \\
\hline alfa & 0.05 \\
\hline $\mathrm{df}$ & 3 \\
\hline CHINV & 7.8147 \\
\hline CHIDIST & 0.4679 \\
\hline
\end{tabular}

Table 4. Verification of the hypothesis $\mathrm{H} 2_{0}$

\begin{tabular}{cc}
\hline CHI-SQUARE & 11.0697 \\
\hline $\mathrm{alfa}$ & 0.05 \\
\hline $\mathrm{df}$ & 3 \\
\hline CHINV & 7.8147 \\
\hline CHIDIST & 0.0114 \\
\hline
\end{tabular}




\subsection{Motivation for introduction of local coefficients}

The reasons that lead to the coefficient introduction in municipalities were determined by using open-ended questions, which were grouped into semantic categories subsequently.

The graph below (Fig. 6) shows the most common motivation for the introduction of local coefficients. It was an increase in municipalities' revenues generally (53\%) or the need to fund specific projects (16\%).

Some of the reasons were based on the specifics of a municipality. There were neglected properties in some municipalities and by introducing the coefficient of 5 , the municipality has led owners to better care of the property or selling it. Conversely, the amount of tax is compensated citizens who live and look after their property with contributions.

The higher immovable property tax was used to improve the environment in the municipalities and services provided to their citizens. Thus the quality of life was improved and the value of the property was increased, while a collection of the immovable property tax did not even cover costs such as public lighting.

An increase in tax revenues through the determination of local coefficients also occurs in municipalities, which are industrial and on whose territory large business companies have their immovable property. Then, the tax revenue consists mainly of taxes paid by businesses there. It makes $72 \%$ or more in some municipalities (one municipality stated over 95\%) of the tax revenues from immovable property. These are often companies that have their headquarters outside the municipality (especially in large cities such as Prague and Brno) and therefore shared taxes are flowing into the budgets of other cities. Moreover, the costs associated with maintenance of cadastral territory, which is built-up by real estates owned by businesses, are high. Municipalities also want to motivate companies to better use of real estate in the municipality by local coefficients with the aim to secure new jobs, especially for the municipality's citizens.

Municipality's tax revenues are only partly made up of immovable property tax. There are shared taxes which go to a municipal budget in a great deal (income taxes, VAT). Therefore, changes in tax laws and the law on budgetary allocation of taxes have a significant

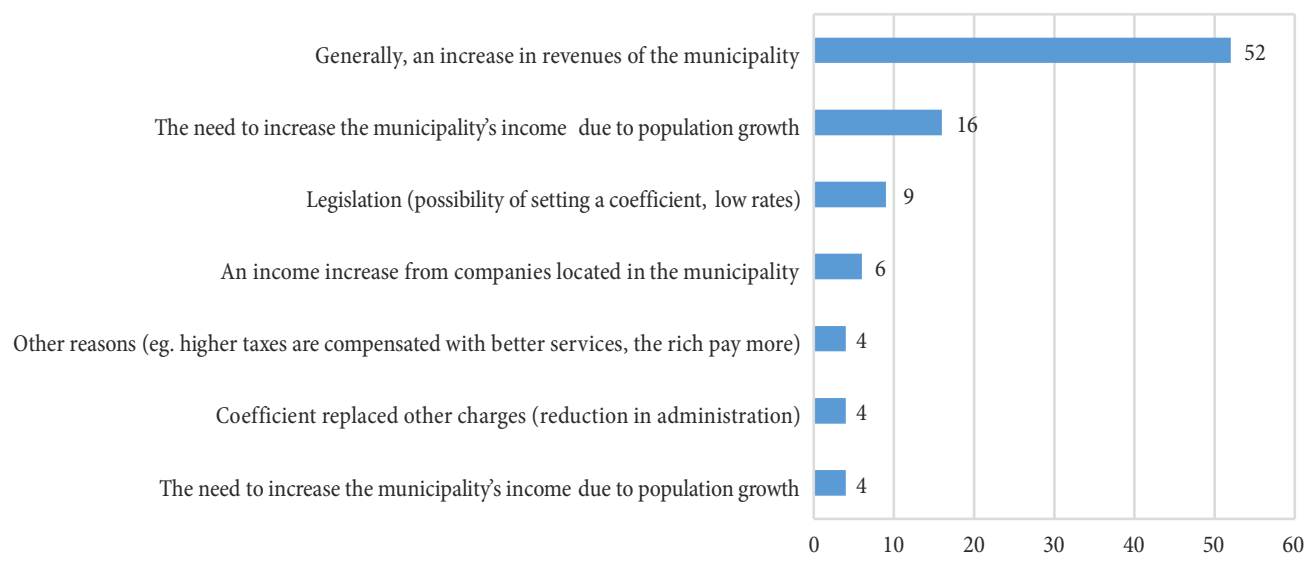

Fig. 6. Motivation for introduction of local coefficients 
effect in reducing or increasing the income of the municipality. Accordingly, the real or expected reduction in shared taxes revenues represents the motivation to establish a local coefficient.

Some municipalities report that the state does not valorise immovable property tax rates (most recently there were changes in 2010). In the context of rising inflation, the real income tax reduces. Municipalities are trying to compensate this difference by introduction of local coefficients.

In municipalities with high population growth and increased construction there is an increase of costs to installation of utilities, street lighting, radio and maintenance of local roads, which creates an incentive for municipalities to introduce local coefficients.

\subsection{Compensation for the immovable property tax increase to citizens}

The introduction of local coefficients increases the real estate tax both for citizens and businesses. There are inspiring actions of individual municipalities in the forms of compensation for an increase in taxes. These have been found out with open-ended questions and grouped into semantic categories. Empirical research showed that some form of compensation is introduced in 45 municipalities representing $46 \%$ of the respondents. Some municipalities have stated several forms of compensation, so they are listed in multiple categories.

As it is clear from the graph (Fig. 7), the most common form of compensation is a reduction, no increase or the total abolition of some fees levied by municipalities (usually a fee for municipal waste removal). This form was chosen by $28 \%$ of the total number of respondents. The complete abolition of the fee brings another advantage which consists in savings in administrative costs associated with its collection, registration and enforcement.

Some municipalities see compensation in improvement made to the appearance of public spaces, building infrastructure and improving the quality of services provided by them. Some of them directly allocate a certain percentage of immovable property tax revenues, which is intended for predetermined investments or repairs, or for organizing cultural and social events. There is an interconnection between revenues from an applied coefficient and a specific project.

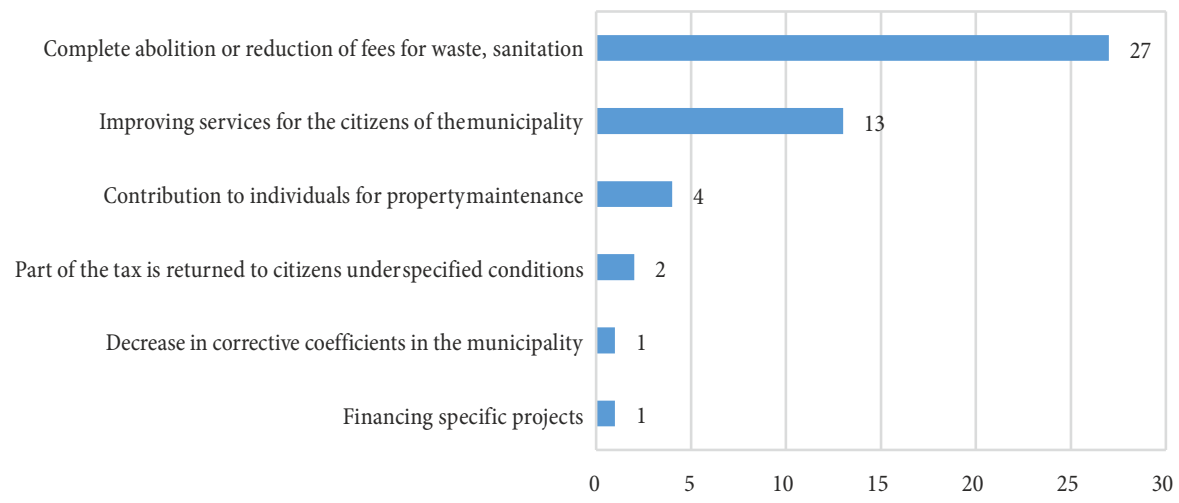

Fig. 7. Compensation for the immovable property tax increase to citizens 
Direct refund of a stipulated amount to citizens is used only by a small portion of municipalities ( $6 \%$ of the total number of respondents). Some contributions are granted just under certain conditions and are bound to property reconstructions. One of the municipalities stated that citizens would receive a differential price, based on the tax increase, upon request. However, only $5 \%$ of the citizens submitted the request. It is obvious that citizens positively perceive an improvement of infrastructure and services in the municipality in the context of the tax increase.

Another variant of compensation for citizens caused by the increase in the local coefficient was a reduction of corrective coefficients according to population in the municipality at the same time. This is a very interesting approach, through which it is possible to reduce or eliminate the impact of the introduction of a local coefficient for owners of construction sites, building houses and units. This may be used primarily by larger municipalities. The mentioned municipality had assigned a corrective coefficient of 2 according to its population. The municipality has set the local coefficient of 2 and simultaneously exercised the options provided by law and reduced the corrective coefficient by three categories to 1 . The impact of the introduction of the local coefficient to owners of construction sites, building houses and units was offset. There is an increase in taxes for owners of other buildings or land (according to the law).

\section{Conclusions}

Fiscal decentralization leads to allocative efficiency associated with possible adaptation to local conditions. It also leads to an increased political accountability thanks to the proximity of voters. Some of fiscal decentralization is implemented in the Czech Republic by taxing immovable property.

Immovable property tax imposed and tax revenues are particularly influenced by changes in legislation each year. Orderly real estate records kept in the cadastre and clarification of the ownership contribute to an increasing trend in tax revenues significantly. This enables an efficient control and searching activity of tax offices. Immovable property tax revenues are low in the Czech Republic in comparison with other taxes, which is mainly due to the structure of the tax base. The tax base assessment is subject to criticism, which is not based on the property value reflecting inflation. In terms of the budget, municipalities have some problems arising out of balancing income and expenditure as public expenditure is subject to inflation.

The immovable property tax is not a crucial item within the total revenues of municipalities. However, it is a stable and easily predictable income the municipality may count on within its budget. It is the assigned tax and a municipality can decide on its amount. As it is apparent both from the statistics and primary research, municipalities are still afraid of using possible legislative tools leading to an increase in immovable property tax revenues. Almost $92 \%$ of municipalities still postpone the introduction of a local coefficient, be it inhabitants' fear of raising taxes or insufficient orientation of the municipal council in the mentioned issue. 
The merits of increasing municipality's autonomy in determining the amount of tax could be the fact that the amount of tax reflects then the specificities and needs of the community. In addition, a higher tax burden, especially in smaller municipalities, is not perceived negatively by taxpayers if the transparency in the use of gained revenues is ensured. The principle of subsidiarity is fulfilled as follows. Decision-making and accountability in public affairs takes place at the lowest level of public administration that is closest to citizens. Municipalities have the option to edit tax components and consequently can manage its revenues.

Municipalities do not have the opportunity to influence the shared tax revenues. Nevertheless, they are sure they will get a certain amount of funds under the statutory rules regardless of their activities. On the other hand, municipalities may influence the immovable property tax revenues. Determining coefficients, especially the local ones, is an important decision that the municipality should consider carefully. Through increased taxes, high coefficients can influence decisions of citizens and companies in the construction of new properties and thus affect the development of the municipality. On the other hand, municipality's inactivity when determining coefficient may result in a lack of funds for necessary investments.

\section{Funding}

This paper was supported by the Ministry of Education, Youth and Sports Czech Republic within the Institutional Support for Long-term Development of a Research Organization in 2015 .

\section{References}

Act No. 338/1992 Coll. 1992. On immovable property tax, as amended [online], [cited 15 May 2015]. Available from Internet: http://www.zakonyprolidi.cz/cs/1992-338

Bečica, J. 2014. Municipalities and assigned taxes, Business trends 4(4): 4-11.

Bird, R. M. 2010. Local government finance: trends and question, IEB'S World Report on Fiscal Federalism: 10-23. http://dx.doi.org/10.2139/ssrn.1659807

Bird, R. M. 2011. Subnational taxation in developing countries: a review of the literature, Journal of International Commerce, Economics and Policy 2(1): 139-161. http://dx.doi.org/10.1142/S1793993311000269

Birch, J.; Sunderman, M. 2013. Regression modelling for vertical and horizontal property tax inequity, Journal of Housing Research 23(1): 89-104.

Blöchliger, H. 2015. Reforming the tax on immovable property: taking care of the unloved, OECD Economics Department Working Papers, No. 1205. Paris: OECD Publishing.

Brunner, E. J.; Ross, S. L.; Simonsen, B. K. 2015. Homeowners, renters and the political economy of property taxation, Regional Science and Urban Economics 53: 38-49.

Coombs, C. K.; Sarafoglou, N.; Crosby, W. 2012. Property taxation, capitalization, and the economic implications of raising property taxes, International Advances in Economic Research 18(2): 151-161. 
European Commission. 2015. Commission staff working document country report Czech Republic 2015 [online], [cited 15 May 2015]. 46 p. Available from Internet: http://ec.europa.eu/europe2020/pdf/ csr2015/cr2015_czech_cs.pdf

European Union. 2014. Taxation trends in the European Union. Data for the EU Member States, Iceland and Norway. Publications Office of the European Union, Luxembourg.

FAO Land Tenure Studies. 2004. Decentralization and rural property taxation [online], [cited 22 August 2015]. Available from Internet: http://www.fao.org/docrep/007/y5444e/y5444e00.htm

Haider-Markel, D. P. 2014. Oxford handbook of state and local government. Oxford: Oxford University Press.

Hájek, L.; Režný, L. 2014. 20 let vývoje české ekonomiky - srovnání se Slovenskem, E\&M Ekonomie a Management 17(1): 19-31.

Horne, R.; Felsenstein, D. 2010. Is property assessment really essential for taxation? Evaluating the performance of an "Alternative Assessment" method, Land use policy 27(4): 1181-1189.

Liberati, P.; Sacchi, A. 2013. Tax decentralization and local government size, Public Choice 157(1): 183-205.

Marková, H. 2007. Own or shared taxes for municipalities?, in Days of Public Law, 19-20 November 2007, Masaryk University, Brno.

MFCR. 2014. Fiscal data for the Czech Republic [online], [cited 5 May 2015]. Available from Internet: http://www.mfcr.cz/cs/verejny-sektor/hospodareni/uzemni-rozpocty/statni-zaverecny-ucet-uzemnich-rozpoctu/2014/szu-uzemnich-rozpoctu-2014-21891

Mrkývka, P. 2003. Podatek od nieruchomości w Republice Czeskiej, Chapter 2 in L. Etel (Ed.). Europejskie systemy opodatkowania nieruchomości. Warszawa: Kancelaria Sejmu.

OECD. 2010. OECD Economic Surveys: Czech Republic 2010. Paris: OECD Publishing.

OECD. 2011. OECD Economic Surveys: Czech Republic 2011. Paris: OECD Publishing.

Presbitero, A. F.; Sacchi, A.; Zazzaro, A. 2014. Property tax and fiscal discipline in OECD countries, Economics Letters 124(3): 428-433.

Radvan, M. 2007. Zdanění majetku v Evropě. 1th ed. Praha: C. H. Beck.

Ramík, J.; Perzina, R. 2014. Microsoft excel as a tool for solving multicriteria decision problems, Procedia Computer Science 35: 1455-1463. http://dx.doi.org/10.1016/j.procs.2014.08.206

Roubínek, P; Kladivo, P.; Halás, M.; Koutský J.; Opravil, Z. 2015. Changes in the financing of municipalities and local governments of selected cities: possible effects on disintegration processes and municipal policy, E\&M Ekonomie a Management 18(1): 134-150.

Sedmihradská, L. 2013. Daňová pravomoc obcí u daně z nemovitostí v České republice a na Slovensku, Acta Oeconomica Pragensia 1: 68-80.

Slack, E. 2011. The property tax - in theory and practice, IMFG papers on Municipal Finance and Governance 2011(2): 1-17.

Smiková, M.; Sedmihradská, L. 2011. Daň z nemovitostí na Slovensku, Obec \& Finance 3: 34-35.

Smith, S. M.; Bryson, P. J.; Cornia, G. C. 2011. The view from city hall: local perceptions of intergovernmental fiscal relations in the Czech Republic, Communist and Post-Communist Studies 44(1): 99-110.

Štreimikiené, D. 2015. Impact of environmental taxes on sustainable energy development in Baltic states, Czech republic and Slovakia, E\&M Ekonomie a Management 18(4): 4-23.

Tax administration. 2015. The annual reports of the Czech tax administration 1999-2014 [online], [cited 5 May 2015]. Available from Internet: http://www.financnisprava.cz/

UN-HABITAT. 2013. Property tax regimes in Europe. Nairobi: UN-HABITAT. 
Zámečník, M.; Klubíčková, K.; Hejlová, H.; Vakrman, T.; Filipec, P. 2011. Trh práce a zboží - daňová struktura, Chapter 4 in M. Mejstř́k (Eds.). Rámec strategie konkurenceschopnosti. 1th ed. Praha, Ưrad vlády České republiky, Národní ekonomická rada vlády (NERV).

Žibik, N.; Mitrović, D. 2006. Development of a Real Property Appraisal and Taxation System in Slovenia [online], [cited 5 May 2015]. Fiscal Decentralization Initiative for Central and Eastern Europe. Available from Internet: http://pdf.usaid.gov/pdf_docs/Pnadk286.pdf

Jana JANOUŠKOVÁ, PhD, is an Associate Professor on Silesian University in Opava, School of business administration in Karviná, (Department of Finance and Accounting) Czech Republic. She lectures in courses Taxation and Tax Policy of the Czech Republic, Application of tax law, Tax accounting, Taxation of the property and consumption. Her research interests are taxation and tax policy, social insurance, tax policy of local government units. She is author of many papers, published in international peer-reviewed journals and books or chapters in books. She has been involved in the research projects funded by the Czech Science Foundation.

Šárka SOBOTOVIČOVÁ, PhD, is a Senior Lecturer on Silesian University in Opava, School of business administration in Karviná, (Department of Finance and Accounting) Czech Republic. She lectures in courses Taxation and Tax Policy of the Czech Republic, Consumption taxation, Taxation of property and consumption, Entrepreneurs tax record. Her research interests are Value added tax and property taxation. She is author or co-author of many papers, published in international peer-reviewed journals and several chapters in books. 